Article

\title{
Educators' Psychosocial Burdens Due to the COVID-19 Pandemic and Predictive Factors: A Cross-Sectional Survey of the Relationship with Sense of Coherence and Social Capital
}

\author{
Yasue Fukuda ${ }^{1, *(D)}$ and Koji Fukuda ${ }^{2}$ \\ 1 Faculty of Pharmaceutical Sciences, Suzuka University of Medical Science, Suzuka 513-8670, Mie, Japan \\ 2 Faculty of Political Science and Economics, Waseda University, Tokyo 169-8050, Japan; fukudak@waseda.jp \\ * Correspondence: yfukuda@suzuka-u.ac.jp; Tel.: +81-59-373-7030
}

\section{check for}

updates

Citation: Fukuda, Y.; Fukuda, K.

Educators' Psychosocial Burdens Due to the COVID-19 Pandemic and Predictive Factors: A Cross-Sectional Survey of the Relationship with Sense of Coherence and Social Capital. Int. J. Environ. Res. Public Health 2022, 19, 2134. https:// doi.org/10.3390/ijerph19042134

Academic Editors: Lawrence Palinkas and Paul B. Tchounwou

Received: 18 December 2021 Accepted: 10 February 2022 Published: 14 February 2022

Publisher's Note: MDPI stays neutral with regard to jurisdictional claims in published maps and institutional affiliations.

Copyright: (c) 2022 by the authors. Licensee MDPI, Basel, Switzerland. This article is an open access article distributed under the terms and conditions of the Creative Commons Attribution (CC BY) license (https:// creativecommons.org/licenses/by/ $4.0 /)$.

\begin{abstract}
This study aims to identify the social and psychological burdens placed on educators during the third wave of the COVID-19 pandemic in Japan and to propose an optimal form of support. We investigated educators' perceptions of psychological and socioeconomic anxieties and burdens, sense of coherence, and social capital using a questionnaire survey of 1000 educators in January 2021. Multivariate regression analyses were conducted to analyze the associations between the variables. Results: Approximately $80 \%$ of the respondents considered COVID-19 a formidable, life-threatening illness. Our results revealed that the higher the social capital, the greater the fear of COVID-19, and the higher the sense of coherence, the lower this fear. Conclusions: The anxiety burden of implementing infection prevention was higher than the anxiety burden associated with distance learning. The predictive factors for educators' perceptions of burden included sense of coherence, gender, and age. Our findings suggest the importance of having the government and educational institutions provide multidimensional assistance that matches educators' individual characteristics.
\end{abstract}

Keywords: COVID-19; educator; sense of coherence; social capital; social and psychological burdens

\section{Introduction}

The coronavirus disease (COVID-19) pandemic has necessitated the implementation of stringent infection countermeasures. However, equally important is the continuation of educational activities, not only at sites of medicine but also at educational sites that entail numerous group activities [1]. There are concerns among young people in their teens and 20 s about infections caused by the variants of the coronavirus, as well as about the spread of household infections from young to old people [2,3]. Since schools conduct countless group activities, there has been considerable concern about the emergence of clusters [4-7]. Schools in Organisation for Economic Cooperation and Development (OECD) countries were closed for at least 10 weeks [8]. Thus, during the COVID-19 crisis, the educational community made efforts to sustain their educational activities by using the Internet, ondemand, and other modes. Nonetheless, according to Hanushek and Woessmann [9], school closures due to COVID-19 in 2020 catalyzed a 10\% reduction in students' skills, corresponding to a $1.5 \%$ reduction in the United States of America's gross domestic product. This triggered drastic changes in educational methods, including a shift to online classes $[8,10,11]$. Moreover, educational inequality among students due to differences in family environments [12] and mental health issues were pointed out [13-15], which led to growing calls to "liberate" the schools. Not only Japan but also other countries such as Spain and Australia reopened their schools despite not having made sufficient preparations.

On the one hand, the reopening of schools has huge benefits for the students; there are also significant advantages for families, as parents are better able to concentrate on work [16]. However, the reopening of schools is a tradeoff with infection risks, engendering 
problems such as how to strike a balance between maintaining the quality of education and securing educational opportunities while preventing infections $[17,18]$. The outbreak of COVID-19 was a turning point for teachers to adopt a variety of measures and programs to guarantee the quality of education, such as using both remote and face-to-face modalities $[19,20]$.

There have been many problems with the Internet-based education provided during the pandemic; these include insufficient communication between the students, as well as between students and teachers [21,22]. As a result of remote education, teachers are forced to cut their rest time, even as they are at home, and send emails to parents and students to answer their individual questions. Furthermore, educators need to spend a lot of time and energy to prevent student infections, while also ensuring the quality of education [8,23]. Policy changes were made in line with the phases of the COVID-19 pandemic; these included transitioning from traditional face-to-face classes to online classes, resuming face-to-face classes from online classes, and using a hybrid modality [10].

During the COVID-19 crisis, anxiety has been increasingly reported among many educators [24]. There are many studies on the mental health of medical professionals, considering their status as essential workers [24-26]. The same is true for educators, as they too deal with the COVID-19 pandemic as frontline workers who seek to guarantee continued education [27]. While several studies have been conducted on the mental health of teachers and students [28-31], the factors that influence educators' perceptions of increased burden and anxiety, or deteriorating mental health status, have not yet been identified. With regard to the provision of education, fear of COVID-19 and the associated burdens are to be dealt with by the educator-specifically, the financial burden, time consumption, physical and mental health effects of infectious disease countermeasures, and the burden of providing distance education with family members and colleagues.

A sense of coherence (SOC) is regarded as an orientation (in other words, part of an individual's personality) toward an adaptive nature that enables a person to effectively deal with unfavorable experiences [32,33].

Human health is not solely determined by biological factors. The health status is influenced by individual social backgrounds and problems. These social factors affecting health are called social determinants of health (SDH) [34]. Research on social capital can be traced back to the work of Hanifann [35], who discussed school education and communities. However, this concept was popularized after a series of sociological research studies by Bourdieu [36]. This series was succeeded by sociological research on the relationship between the achievement of youth education and the community by Coleman [37]. Furthermore, Putnam [38] put forth a political science perspective and highlighted the reality regarding the negative impact of reduced social capital as a collective resource for political participation, education, economy, and health. Additionally, social capital acts as a personal resource with characteristics that influence individual education, employment opportunities, health, and as a collective resource within the nation context, it influences social organization. Social capital research has been guided by the major trends of these two characteristics. The study as a personal resource argues that an individual's income, health status and family status are related to the social network.

Existing research on the effects of social capital as a collective resource focuses on "social factors as an environment," including social and public health policies. Berkman and Kawachi's research, which focuses on social capital in relation to health, is also part of the research that relies on the above-mentioned previous research, regarding a personal and collective resources, rather than a unique perspective [39]. Several previous studies have suggested the relationship between social capital and health, and SDH has been shown to affect nearly $60 \%$ of individual health [40]. Moreover, a strong association has been indicated between social capital and COVID-19, and a study reports that the existence of social capital leads to an information network and is useful for infection control. However, another study reveals that excessive social capital results in the spread of infectious diseases over time [41]. 
Fear of COVID-19 has also been reported to impose stress on many essential workers, such as healthcare professionals [24,25], but educators also come in contact with multiple people and groups, including students, and several are infected. This occurrence of illness results in fear and stress; however, these factors have not been fully studied amidst the challenges of educators.

By clarifying the relationship between SOC and everyday perceptions due to a lack of social connectivity or social capital, it can better help to understand the role of educators' individual characteristics. Studies evaluating the psychosocial burden on educators in the COVID-19 era have recently emerged. Owing to the increased burden on educators, there are concerns about the extent to which burnout syndrome and turnover at educational sites increase teachers' job burdens. There are also concerns that this increased burden on educators may trigger burnout and turnover [42,43]. Changes in the pandemic situation can also affect the well-being of educators, with the added psychosocial and economic burden, including the risk of spreading COVID-19 infection to educators, their families, and students. Under these circumstances, it is important to investigate how psychological stress develops and accumulates in teachers. Identifying the predictive factors would make it possible to support educational institutions and assist individual teachers.

Therefore, as shown in Figure 1, the purpose of this paper is to elucidate the impact of educators' burden and educational environment on the use of both online and face-to-face classes according to the continuous spread and change of infectious diseases.

\begin{tabular}{|c|c|c|}
\hline \multirow{6}{*}{$\begin{array}{l}\text { Educators' } \\
\text { occupational, } \\
\text { social, } \\
\text { psychological } \\
\text { burdens and } \\
\text { anxiety } \\
\text { concerning } \\
\text { COVID-19 }\end{array}$} & \multirow{6}{*}{$\begin{array}{l}\text { Stress Factors: } \\
\text { 1. } \quad \text { Economic burden } \\
\text { 2. } \quad \text { Time constraint } \\
\text { 3. } \quad \text { Infection control measures } \\
\text { 4. } \quad \text { Distance education technostress } \\
\text { 5. } \quad \text { Maintaining social ties }\end{array}$} & \multirow{8}{*}{$\begin{array}{l}\text { - Predictors, influencing } \\
\text { factors } \\
\text { - Personal attributes } \\
\text { Gender, age, } \\
\text { institution, } \\
\text { educational } \\
\text { background, etc. } \\
\text { - SOC } \\
\text { - Social capital } \\
\text { - Fear of COVID-19 }\end{array}$} \\
\hline & & \\
\hline & & \\
\hline & & \\
\hline & & \\
\hline & & \\
\hline & $\widehat{૫}$ & \\
\hline & $\begin{array}{l}\text { Support from governments and } \\
\text { educational institutions }\end{array}$ & \\
\hline
\end{tabular}

Figure 1. The burden of educators and the impact on the educational environment during COVID-19. (SOC $=$ sense of coherence). We formulated this figure of analytical approach to the social and psychological burden imposed by COVID-19 on educators, by referring to the method of NIOSH approach to Job Stress [44,45].

This is the first study to answer the above questions and clarify the national-level situation of all educational institutions. At the same time, we investigated whether individual differences arose in terms of educators' perceptions of increased burden and anxiety, and if they were apparent, we identified the factors that influenced such differences. The influence on burden and anxiety of educators due to differences in individual attributes would help in designing tailormade support for educators. It can also contribute to quality assurance of education and better human resources management [46].

\section{Materials and Methods}

\subsection{Study Design and Participants}

A cross-sectional survey was conducted online from January 8 to 11, 2021 across educational institutions in Japan, and multivariate analysis was employed on the results of questionnaires obtained from the responses of 1000 employed educators. 
A minimum sample size estimate of 385 was derived based on a normal approximation of the binomial distribution with a finite population correction applied (assuming an observed percentage of participants who chose a specific response option of $50 \%$ ). Based on the statistics of the Ministry of Education, Culture, Sports, Science and Technology, it reflected the proportion of the population size of about one million educators, with a confidence level of $95 \%$ and a margin of error of $5 \%$. Based on previous studies, we chose to collect 1000 questionnaires to improve the validity of the survey.

The target participants were men and women who were 20 years of age or older, were members of Japanese educational institutions, and expressed their willingness to participate after receiving an explanation of the research plan on the Internet. Participants who differed from the registered contents, such as age and gender, were excluded from the survey. In addition, to eliminate participants who did not read the five-limb selection question carefully, we set up a trick question asking participants to choose a specified symbol. Those who did not select the specified symbols were excluded. Gender was evenly assigned to each age group, and the questionnaire was distributed to 6000 people who registered their occupations as educators. A total of 1964 people agreed to participate, but we excluded 326 whose survey responses did not match their age, gender, and educational background at the time of enrollment. The number of complete answers was 1175, of which 151 did not answer the trick question properly and were excluded. We also excluded data from 24 participants who recorded significantly shorter response times compared to the others. Finally, the responses of 1000 participants, which were complete and consistent, were used for the analysis.

\subsection{Measures}

The questionnaire items and contents were devised based on previous studies and through discussions among the researchers. The survey included the following sections:

\subsubsection{Sociodemographic Characteristics}

Distinctions such as demographic characteristics (attributes), including gender and age group, affiliated educational institution (type), education, and fixed-term or full-time employment were noted.

\subsubsection{SOC Scale}

The Japanese version of the SOC-13 scale was used to measure the psychological stress resistance [47]. It consists of 13 items rated on a seven-point Likert scale and has three subscales: meaningfulness (four items), comprehensibility (five items), and manageability (four items). SOC is used as an index to represent the meaning of situations and diseases, as well as their understanding and manageability. The Cronbach's reliability coefficient alpha was 0.803 .

\subsubsection{Health-Related Social Capital}

We measured social capital using Saito et al.'s [48] social capital index, which comprises three subscales. The subscales of residential participation (five items) and social cohesion with the regional community (three items) were scored on a four-point Likert scale ( 1 = strongly agree/yes, 2 = moderately agree/yes, $3=$ neither, $4=$ disagree/no) Participants who chose strongly or moderately agree/yes were coded 1 ; others were coded 0 . On the mutual support subscale (three items), participants who reported participating in the community at least once a month, having trust, and engaging in mutual help were scored 1. We assigned a score of 0 if participants chose the options of "don't know" or participated in the community less than once a month. The Cronbach's reliability coefficient for this scale was 0.693 . 


\subsubsection{Fear of COVID-19}

Five items concerning fear of COVID-19 were included based on previous studies [49-52]. These items were scored using a five-point Likert scale $(1=$ strongly disagree, $2=$ disagree, $3=$ neither, $4=$ agree, $5=$ strongly agree).

Previous surveys on fear and anxiety regarding COVID-19 included, in addition to emotional questions, questions pertaining to symptoms such as "sweaty hands," "pounding heart," and "insomnia" [49-52]. After an internal discussion among the researchers and a pilot survey with the educators, we decided to adopt the insomnia item alone, as it is reported to be caused by fear of COVID-19 [53].

We also changed an item from "It makes me uncomfortable to think about corona" to "Prejudice and discrimination against patients with COVID-19 is emerging." This is because discrimination on the basis of infection is an important issue given the spread of the infection [54]. Cronbach's alpha was 0.663.

\subsubsection{Psychosocial Burden during the COVID-19 Pandemic in the Educational Environment}

After a discussion, the researchers drew up the questionnaire items on the perceptions of psychosocial burden/anxiety experienced by educators concerning education during the COVID-19 pandemic.

Aperribai et al. [28] explored educators' mental and physical health during the COVID19 pandemic, while Kim et al. [55] examined the psychological stresses and burdens of educators associated with the reopening of schools, classifying them into five categories. Based on these studies, we included 17 items across the following five areas: (1) anxiety/burden regarding infection and preventive measures at sites of education (four items); (2) anxiety/burden due to the need to cope with the changes in class format (four items); (3) economic anxiety/burden (three items); (4) a perception of increased burden based on shortage of, and reduction in, hours of sleep, rest time, study time, etc. (three items); and (5) issues of social relationships (three items). Responses were evaluated on a five-point Likert scale ( $1=$ strongly disagree, $2=$ disagree, $3=$ neither, $4=$ agree, $5=$ strongly agree $)$. Cronbach's alpha was 0.931 .

\subsection{Ethical Considerations}

This study was approved by the Research Ethics Review Board of Waseda University (No 2020-297). Educators were informed of the research plan and asked to check a box to indicate their consent to participate. Those who agreed to participate proceeded to the questions. Participants could withdraw their consent in the middle of an answer and cancel their participation. In such a case, the person's data would be excluded from the analysis.

\subsection{Statistical Analysis}

The demographic characteristics of interest were as follows: gender, age group, affiliated educational institution, and educational background. Continuous variables were summarized as means and standard deviations. Categorical variables were summarized as frequencies and percentages. The fear related to COVID-19 and the burden on teachers when it becomes widespread is a measure that combines several questions. As in previous studies, each rating scale was treated as a continuous variable and the association between the fear of COVID-19 and predict factor; Based on previous research, on the assumption that the fear of COVID-19, the burden on educators due to COVID-19, and their influential factors are in a linear relationship, a linear regression analysis was performed in this study $[56,57]$. We performed multivariate linear regression analyses to examine the associations between the outcome variables (SOC, fear of COVID-19, and burden and anxiety regarding education during the COVID-19 pandemic) and the independent variables (social capital and sociodemographic characteristics). Cronbach's alpha was used for reliability analysis. Data were analyzed using SPSS Statistics version 26 (IBM Corp., Armonk, NY, USA). The significance level was set at $5 \%$. 


\section{Results}

\subsection{Sociodemographic Characteristics}

Table 1 shows the participants' sociodemographic characteristics.

Table 1. Participants' sociodemographic characteristics.

\begin{tabular}{|c|c|c|c|}
\hline & & Frequency $(n)$ & $\%$ \\
\hline \multirow[t]{2}{*}{ Gender } & Men & 769 & 76.9 \\
\hline & Women & 231 & 23.1 \\
\hline \multirow[t]{5}{*}{ Age group } & $20 s$ & 29 & 2.9 \\
\hline & $30 s$ & 111 & 11.1 \\
\hline & $40 s$ & 206 & 20.6 \\
\hline & $50 \mathrm{~s}$ & 408 & 40.8 \\
\hline & $60 s$ & 246 & 24.6 \\
\hline \multirow[t]{3}{*}{ Academic history } & University graduate & 651 & 65.1 \\
\hline & Graduate school graduate & 314 & 31.4 \\
\hline & Other & 35 & 3.5 \\
\hline \multirow[t]{4}{*}{ Degree } & B.A. & 651 & 65.1 \\
\hline & M.A. & 163 & 16.3 \\
\hline & Ph.D. & 151 & 15.1 \\
\hline & None & 35 & 3.5 \\
\hline \multirow{3}{*}{ Form of employment } & Full-time & 811 & 81.1 \\
\hline & Fixed term & 65 & 6.5 \\
\hline & Part-time & 124 & 12.4 \\
\hline \multirow{5}{*}{$\begin{array}{l}\text { Affiliated educational } \\
\text { institution }\end{array}$} & Elementary school & 248 & 24.8 \\
\hline & Middle school & 183 & 18.3 \\
\hline & Senior high school & 292 & 29.2 \\
\hline & Technical college; junior college & 66 & 6.6 \\
\hline & University & 211 & 21.1 \\
\hline \multirow{2}{*}{$\begin{array}{l}\text { Receiving outpatient } \\
\text { treatment: Yes/No }\end{array}$} & Yes & 430 & 43 \\
\hline & No & 570 & 57 \\
\hline
\end{tabular}

At the time of the survey, the number of infected persons had risen for the third time since the beginning of the pandemic. In response, elementary, middle, and high schools temporarily conducted remote classes. Following a request from the Ministry of Education, Culture, Sports, Science and Technology, these schools reopened in May 2020, and universities were asked to make efforts to increase face-to-face classes after September 2020.

According to data from the Ministry of Education, Culture, Sports, Science and Technology in 2020, the total number of educators in elementary schools, junior high schools, high schools, junior colleges, universities, and graduate schools in Japan was 1,088,212. The proportions of female teachers were $62 \%$ in elementary school, $43 \%$ in junior high school, $32 \%$ in high school, and $25 \%$ in college.

We conducted a questionnaire survey considering Japanese educators' gender ratio, and in terms of the gender ratio of our participants, three-quarters were men. Furthermore, $64 \%$ were over 50 years of age. As for affiliated educational institutions, $24.8 \%$ worked in elementary schools, $18.3 \%$ in middle schools, $29.2 \%$ in high schools, $6.6 \%$ in junior colleges, and $21.1 \%$ in universities.

\subsection{SOC Scale and Predictive Factors}

The average SOC score was $55.61 \pm 10.54$ (range: 13-91), which is similar to the average SOC of Japanese people [47].

Table 2 shows the results of a multivariate analysis of SOC and the participants' attributes. 
Table 2. Factors influencing sense of coherence: linear multivariate regression analysis.

\begin{tabular}{|c|c|c|c|c|c|c|c|}
\hline & \multicolumn{2}{|c|}{$\begin{array}{l}\text { Non-Standardized } \\
\text { Coefficient }\end{array}$} & \multirow{2}{*}{$\begin{array}{c}\begin{array}{l}\text { Standardized } \\
\text { Coefficient }\end{array} \\
\text { Beta }\end{array}$} & \multirow{2}{*}{$t$-Value } & \multirow{2}{*}{$\begin{array}{l}\text { Significant } \\
\text { Probability }\end{array}$} & \multicolumn{2}{|c|}{ 95\% Confidence Interval } \\
\hline & B & SD & & & & Lower Limit & Upper Limit \\
\hline (Constant) & 45.439 & 2.892 & & 15.712 & 0.000 & 39.763 & 51.114 \\
\hline Gender & -0.560 & 0.857 & -0.022 & -0.653 & 0.514 & -2.241 & 1.122 \\
\hline Age group & 1.829 & 0.362 & 0.179 & 5.050 & 0.000 & 1.119 & 2.540 \\
\hline $\begin{array}{l}\text { Affiliated educational } \\
\text { institution }\end{array}$ & 0.317 & 0.320 & 0.043 & 0.993 & 0.321 & -0.310 & 0.944 \\
\hline Form of employment & 0.259 & 0.521 & 0.017 & 0.497 & 0.620 & -0.764 & 1.281 \\
\hline Academic history & -3.342 & 1.890 & -0.148 & -1.768 & 0.077 & -7.052 & 0.368 \\
\hline Degree & 1.699 & 1.263 & 0.120 & 1.345 & 0.179 & -0.780 & 4.178 \\
\hline $\begin{array}{l}\text { Receiving outpatient } \\
\text { treatment: } \mathrm{Y} / \mathrm{N}\end{array}$ & 1.875 & 0.705 & 0.088 & 2.662 & 0.008 & 0.493 & 3.258 \\
\hline
\end{tabular}

Note: $\mathrm{SD}=$ standard deviation; adjusted $\mathrm{R}^{2}=0.0 .37$

No relationships were observed between SOC and gender, affiliated educational institution, or academic history. However, a relationship was observed between SOC and age group and the status of receiving outpatient treatment (yes or no) $(p<0.01)$. In the comparison of age groups between the 50s and $60 \mathrm{~s}$ and below $40 \mathrm{~s}$, the results indicated SOC to be significantly higher among older adults, such as those in their 50s and 60s (Tukey's test, $p<0.01$ ).

\subsection{Social Capital in the Region}

The average social capital score was $4.09 \pm 2.00$. No relationships were observed between social capital and age group, gender, affiliated educational institution, academic history, or form of employment (Tukey's test, $p>0.05$ ).

\subsection{Anxiety/Fear of COVID-19 and Predictive Factors}

Table 3 shows the statistical results for the participants' descriptions of their fear of COVID-19.

Table 3. Educators' responses regarding fear of COVID-19.

\begin{tabular}{|c|c|c|c|c|c|c|c|c|c|c|c|c|}
\hline & \multicolumn{2}{|c|}{$\begin{array}{l}\text { Strongly } \\
\text { Agree }\end{array}$} & \multicolumn{2}{|c|}{ Agree } & \multicolumn{2}{|c|}{ Neither } & \multicolumn{2}{|c|}{ Disagree } & \multicolumn{2}{|c|}{$\begin{array}{l}\text { Strongly } \\
\text { Disagree }\end{array}$} & \multirow[t]{2}{*}{ Mean } & \multirow[t]{2}{*}{ SD } \\
\hline & $n$ & $\%$ & $n$ & $\%$ & $n$ & $\%$ & $n$ & $\%$ & $n$ & $\%$ & & \\
\hline COVID-19 is a scary disease & 483 & 48.3 & 368 & 36.8 & 99 & 9.9 & 26 & 2.6 & 24 & 2.4 & 4.26 & 0.914 \\
\hline $\begin{array}{l}\text { My life is being threatened } \\
\text { by COVID-19 }\end{array}$ & 373 & 37 & 428 & 43 & 128 & 13 & 45 & 5 & 26 & 2.6 & 4.08 & 0.954 \\
\hline $\begin{array}{l}\text { I cannot sleep at night when I } \\
\text { think about COVID-19 }\end{array}$ & 21 & 2 & 69 & 7 & 207 & 21 & 242 & 24 & 461 & 46.1 & 1.95 & 1.064 \\
\hline $\begin{array}{l}\text { Prejudice and discrimination } \\
\text { against patients with } \\
\text { COVID-19 is emerging }\end{array}$ & 266 & 27 & 449 & 45 & 178 & 18 & 53 & 5 & 54 & 5.4 & 3.82 & 1.054 \\
\hline $\begin{array}{l}\text { News about COVID-19 } \\
\text { sometimes makes me } \\
\text { anxious and nervous }\end{array}$ & 126 & 12.6 & 361 & 36.1 & 257 & 25.7 & 152 & 15.2 & 104 & 10.4 & 3.25 & 1.171 \\
\hline
\end{tabular}


The scores showing insomnia to be caused by COVID-19 were low (1.95 \pm 1.06$)$. However, the scores for "COVID-19 is a scary disease" and "My life is being threatened by COVID-19" were both high (4.26 \pm 0.91 and $4.08 \pm 0.95$, respectively). Thus, discrimination against people with COVID-19 and fear of social exclusion (3.85 \pm 1.05$)$ were more common than experiencing anxiety and nervousness upon encountering news about COVID-19 (3.25 \pm 1.17$)$. The average of the sum total was $17.94 \pm 3.37$ (range: $5-25)$.

Table 4 shows the results of a multivariate analysis of fear/anxiety regarding COVID19 and the participants' sociodemographic characteristics, SOC, and social capital.

Table 4. Fear/anxiety regarding COVID-19 and influencing factors (linear multivariate regression analysis).

\begin{tabular}{|c|c|c|c|c|c|c|c|}
\hline & \multicolumn{2}{|c|}{$\begin{array}{c}\text { Non-Standardized } \\
\text { Coefficient }\end{array}$} & \multirow{2}{*}{$\begin{array}{l}\begin{array}{l}\text { Standardized } \\
\text { Coefficient }\end{array} \\
\text { Beta }\end{array}$} & \multirow{2}{*}{$t$-Value } & \multirow{2}{*}{$p$-Value } & \multicolumn{2}{|c|}{ 95\% Confidence Interval } \\
\hline & B & SD & & & & Lower Limit & Upper Limit \\
\hline (Constant) & 18.493 & 0.925 & & 19.992 & 0.000 & 16.678 & 20.308 \\
\hline Gender & 1.335 & 0.264 & 0.165 & 5.060 & 0.000 & 0.817 & 1.852 \\
\hline Age group & 0.174 & 0.109 & 0.053 & 1.591 & 0.112 & -0.041 & 0.388 \\
\hline Workplace & -0.174 & 0.098 & -0.074 & -1.769 & 0.077 & -0.366 & 0.019 \\
\hline Form of employment & -0.017 & 0.161 & -0.003 & -0.107 & 0.915 & -0.333 & 0.299 \\
\hline Degree & -0.817 & 0.389 & -0.182 & -2.100 & 0.036 & -1.581 & -0.053 \\
\hline Sense of coherence & -0.075 & 0.010 & -0.237 & -7.482 & 0.000 & -0.095 & -0.056 \\
\hline Social capital & 0.153 & 0.053 & 0.091 & 2.894 & 0.004 & 0.049 & 0.256 \\
\hline
\end{tabular}

Note: $\mathrm{SD}=$ standard deviation; dependent variable: anxiety about COVID-19; adjusted $\mathrm{R}^{2}=0.043$.

A negative correlation was observed, in which the higher the SOC scores, the lower the fear of COVID-19. The results for men and women (17.04 \pm 3.34 and $18.42 \pm 3.31$, respectively) suggested that women had a significantly greater fear of the disease $(p<0.01)$. Furthermore, there was a positive correlation between social capital and fear of COVID-19, and a negative correlation between fear of COVID-19 and SOC and academic degree.

\subsection{Perception of Psychological, Social, and Economic Burden and Anxiety at Sites of Education}

Table 5 shows the statistical results of the participants' perceptions of increased burden/anxiety at the sites of education. Psychological, social, and financial burdens and anxieties in educational activities were significantly higher for infectious disease-related anxiety than for distance learning $(p<0.01)$. In addition, anxiety and concern about a lack of connections with patients, families, and students were significantly higher than the sense of burden in terms of time and economy $(p<0.01)$ (Tukey's test, $t$-test).

The average of the sum total was $61.11 \pm 12.32$ (range: $17-85$ ).

Table 6 shows the results of multivariate analysis of the perceptions of psychosocial anxiety or burden at the sites of education and the participants' fear of COVID-19, sociodemographic characteristics, SOC, and social capital.

The perceptions of psychological, social, and economic burden and anxiety at sites of education correlated positively with social capital and anxiety about COVID-19. Furthermore, the perceptions of psychological, social, and economic burden and anxiety at sites of education correlated negatively with SOC and age group: the higher the SOC and age group, the lower the perception of psychosocial anxiety/burden. 
Table 5. Burden/anxiety at educational sites due to COVID-19.

\begin{tabular}{|c|c|c|c|c|c|}
\hline $\begin{array}{l}\text { Environment and } \\
\text { Technologies } \\
\text { (Changes in Class } \\
\text { Format) }\end{array}$ & Mean & SD & $\begin{array}{c}\text { Infection } \\
\text { Countermeasures }\end{array}$ & Mean & SD \\
\hline Remote technology & 3.72 & 1.124 & $\begin{array}{l}\text { Anxiety of pupils } \\
\text { and infected persons }\end{array}$ & 4 & 0.922 \\
\hline $\begin{array}{c}\text { Internet } \\
\text { environment }\end{array}$ & 3.59 & 1.115 & $\begin{array}{l}\text { Getting the self, } \\
\text { colleagues, and } \\
\text { family infected }\end{array}$ & 4.01 & 0.925 \\
\hline Support setup & 3.75 & 1.065 & $\begin{array}{l}\text { News about cluster } \\
\text { occurrence }\end{array}$ & 3.85 & 0.97 \\
\hline \multirow[t]{2}{*}{$\begin{array}{l}\text { Increase in dealing } \\
\text { with parents and } \\
\text { students }\end{array}$} & 3.74 & 1.065 & $\begin{array}{l}\text { Tediousness of } \\
\text { infection } \\
\text { countermeasures }\end{array}$ & 3.89 & 0.977 \\
\hline & 3.7 & 1.09225 & & 3.9375 & 0.9485 \\
\hline Total & 14.7950 & 3.81570 & Total & 15.7510 & 3.31300 \\
\hline Time & & & Social relationships & & \\
\hline Shortage of rest time & 3.35 & 1.159 & $\begin{array}{c}\text { Nurturing of } \\
\text { students' sociability }\end{array}$ & 3.8 & 0.907 \\
\hline Lack of sleep & 3.18 & 1.151 & $\begin{array}{l}\text { Students and faculty } \\
\text { becoming isolated }\end{array}$ & 3.58 & 1.014 \\
\hline \multirow[t]{2}{*}{$\begin{array}{l}\text { Reduction in } \\
\text { research/study time }\end{array}$} & 3.22 & 1.113 & $\begin{array}{l}\text { The self and family } \\
\text { becoming isolated }\end{array}$ & 3.3 & 1.071 \\
\hline & 3.25 & 1.141 & & 3.56 & 0.9973333 \\
\hline Total & 9.7470 & 3.10300 & Total & 10.6790 & 2.61205 \\
\hline \multicolumn{6}{|l|}{$\begin{array}{c}\text { Financial/economic } \\
\text { aspects }\end{array}$} \\
\hline $\begin{array}{c}\text { Employment, } \\
\text { economy, anxiety }\end{array}$ & 3.48 & 1.079 & & & \\
\hline $\begin{array}{c}\text { Economic costs of } \\
\text { providing/setting } \\
\text { up PCs }\end{array}$ & 3.44 & 1.081 & & & \\
\hline \multirow[t]{2}{*}{$\begin{array}{l}\text { Insufficient research } \\
\text { fees }\end{array}$} & 3.22 & 1.076 & & & \\
\hline & 3.38 & 1.0786667 & & & \\
\hline Total & 10.1330 & 2.74533 & & & \\
\hline
\end{tabular}

Note. SD = standard deviation; PC = personal computer. 
Table 6. Burden/anxiety at educational sites due to COVID-19 and influencing factors: Linear multivariate regression analysis.

\begin{tabular}{|c|c|c|c|c|c|c|c|}
\hline \multicolumn{8}{|c|}{ Coefficient $^{a}$} \\
\hline & \multicolumn{2}{|c|}{$\begin{array}{l}\text { Non-Standardized } \\
\text { Coefficient }\end{array}$} & \multirow{2}{*}{$\begin{array}{l}\begin{array}{l}\text { Standardized } \\
\text { Coefficient }\end{array} \\
\text { Beta }\end{array}$} & \multirow{2}{*}{$t$-Value } & \multirow{2}{*}{$p$-Value } & \multicolumn{2}{|c|}{ 95\% Confidence Interval } \\
\hline & B & SD & & & & Lower Limit & Upper Limit \\
\hline (Constant) & 48.768 & 3.589 & & 13.589 & 0.000 & 41.726 & 55.811 \\
\hline Gender & 0.599 & 0.871 & 0.020 & 0.688 & 0.491 & -1.109 & 2.308 \\
\hline Age group & -0.742 & 0.356 & -0.062 & -2.084 & 0.037 & -1.440 & -0.043 \\
\hline $\begin{array}{l}\text { Affiliated educational } \\
\text { institution }\end{array}$ & -0.317 & 0.320 & -0.037 & -0.989 & 0.323 & -0.946 & 0.312 \\
\hline Form of employment & -0.922 & 0.524 & -0.051 & -1.758 & 0.079 & -1.951 & 0.107 \\
\hline Degree & -0.545 & 1.271 & -0.033 & -0.428 & 0.668 & -3.039 & 1.950 \\
\hline Social capital & 0.673 & 0.173 & 0.109 & 3.896 & 0.000 & 0.334 & 1.012 \\
\hline $\mathrm{SOC}$ & -0.231 & 0.034 & -0.198 & -6.848 & 0.000 & -0.297 & -0.165 \\
\hline $\begin{array}{l}\text { Anxiety about } \\
\text { COVID-19 }\end{array}$ & 1.559 & 0.105 & 0.423 & 14.791 & 0.000 & 1.352 & 1.765 \\
\hline
\end{tabular}

Note. ${ }^{a}$ Dependent variable: burden of, and anxiety about, education; SD = standard deviation; SOC = sense of coherence.

\section{Discussion}

This study was carried out while a newly emerging infectious disease, COVID-19, had broken out and was not being adequately controlled, even after more than a year, with educators being forced to continue carrying out both infection countermeasures and educational activities. Previous studies that investigated the psychosocial issues faced by educators and students were conducted during the early stages of the COVID19 pandemic or during school lockdown [13-16,21,28-31,53,55,58-60]. Our study shows the subsequent stages during spread and that they converged repeatedly, prolonging the period of infectious diseases. This study is unique and provides insight into the psychological burden of educators. Based on our research findings, we aim to support the long-term exhaustion within the educational field, while ensuring the quality of education in the future.

In this context, we clarified the socio-psychological and economic burden that COVID19 placed on educators. Educators' burden and anxiety arose from the following five factors: (1) economic burden, (2) time constraints, (3) infection control measures, (4) distance education technostress, and (5) maintaining social ties. Educators' burden and anxiety associated with the implementation of education were associated with fear of COVID-19, age, gender, SOC, and social capital.

First, our study suggested that the participants were compelled to continue working as educators while harboring anxieties about education-related concerns such as the spread of infection among students, the impact on their nurturing of sociability, and concerns about isolation. Regarding the fear of an infectious disease and the burden on educators, $80 \%$ of the educators considered COVID-19 to be a formidable disease. Gender differences were recognized, with women being under greater stress than men. This is consistent with a previous study on the fear of COVID-19 among Mexican high school teachers [24]. However, there are few studies on educational stress and burden due to COVID-19. During the ongoing COVID-19 crisis, educators have been requested to conduct classes using both online and face-to-face modes. COVID-19 not only puts people's health at risk but also contributes to mental health and economic problems such as employment instability and burden and anxiety at the sites of education [30]. Educators have been required to engage more frequently with the use of remote education techniques and the Internet, in addition to 
interaction with students and their parents. As a result, educators have less time for research and preparation of teaching materials. Their work time and workload have increased, and especially teachers with chronic illnesses and those living with family members at high infection risk experience heavy material, economic, and mental burdens associated with the need to apply anti-infection measures. There are several studies on the psychological effects of COVID-19 on educators' awareness of the transition to online classes and technostress [29,59,61]. According to Worth and Van den Brande [62], professionals in education are under more stress than those in other professions. In addition, Perryman and Calvert [63] pointed out that teachers are under increasing pressure from school accountability systems. A study, conducted in the University of Jordan, regarding psychological stress during the COVID-19 pandemic found that over half the faculty members were reportedly experiencing stress due to COVID-19 [59]. According to Aperribai et al.'s [28] study on educators' mental health during the lockdown, the observed problems included higher working hours, technical stresses in online classes, inability to directly teach students, and problems related to social relationships in their families and workplaces. However, there are few empirical studies on the impact on educators of the transition from online to face-to-face classes. In addition, there are few reports on the impact of both remote and face-to-face classes on educators and the educational environment. Thus far, most studies have focused on the evaluation of psychological stress experienced by educators using the Perceived Stress Scale and General Health Questionnaire, among others, and have pointed out the need for psychological support [28,64,65]. A study on COVID-19 by Al-Sabba et al. [65] examined the feeling of well-being among university students and faculty members of the Department of Health Psychology at two universities amidst school closures. The morbidity of COVID-19 reveals that symptoms such as insomnia and anxiety occur, negative emotions and happiness decrease. However, improved communication enhances happiness, and happiness is not related to educational background or gender. This finding is also consistent with our research results. According to a study by Eadie et al. [66], a strong positive correlation exists between the educator's and students' well-being among students in their early childhood. This finding can also be generalized to the relationship between educators and students in other age groups, so it is necessary to take measures to reduce the burden on educators. Since our research has revealed stress as an influential factor, we believe that the relationship between educators and students can be improved by providing support to eliminate this factor.

A study by Spadafora et al. [67] examined the relationship between kindergarten teachers' mental health and their care for children and adolescents and indicated that family responsibilities affect their mental health. Since our study did not examine the family composition, future research should examine the effects of family composition and family relationships.

Second, our study found that the higher the SOC score, the lower the burden of education implementation due to commitment. In line with our results, a survey conducted in Nagasaki, Japan, which examined the mental health of high school teachers (measured via the General Health Questionnaire 12) and SOC, found that the higher a person's degree of satisfaction with work, sense of self-control, and SOC, the better the mental health status [68]. It has been pointed out that SOC - a measure of psychological stress-related resilience-and social capital are related to health. To support and reinforce educational activities, educational institutions, the government, and administrative bodies need to provide diverse forms of assistance to alleviate educators' mental and physical stress and reduce their anxiety levels [10,20]. A correlation between psychological stress-related resilience (SOC) and age has also been previously reported [69], supporting the current results. In addition, our study revealed that the ongoing COVID-19 pandemic is increasing educators' anxieties and burdens regarding infection prevention and disease management. According to Lizana et al.'s [70] study on the quality of life of educators during the COVID19 pandemic, the quality of life of women under 45 was significantly reduced compared to pre-pandemic levels. Our study indicates that the burden and anxiety of educators are 
related to age and gender. According to Akour et al.'s [59] study on university faculty members, more than half experienced the fear of being infected with COVID-19 and exhibited social resistivity, which is consistent with our study. According to Penado Abilleira et al. [61], the technostress of older educators transitioning from face-to-face to remote classes is higher than that of younger educators.

Third, our study showed that the higher the social capital, the greater the burden of education during the COVID-19 pandemic. Social capital leads to a teacher's professional identity [71]. Moreover, it can be considered that the higher the professional awareness, the higher the social capital. Our study reveals a relationship between social capital and the high burden of providing education related to factors such as infectious disease control, concerns with family members, and colleagues. More enthusiastic teachers with higher social capital and higher professionalism may be able to deal with various psychological, time, and physical burdens. Regarding the effects of social capital on health, Bai et al. [72] investigated the link between social capital and social distancing among American individuals during the COVID-19 crisis and reported that the higher the social capital, the more socially distant their behavior. This finding can be interpreted as taking preventive action in society to maintain social capital. Our study suggests that during the chronic crisis brought about by the COVID-19 pandemic, sincere educators with higher social capital are taking measures against infection and ensuring the quality of education, with a feeling of burden. In addition, a large study by Bartscher et al. [41] on social capital in the European region pointed out that there is an awareness that it is a citizen's duty to voluntarily ensure social distance. The COVID-19 pandemic has accelerated the spread of online classes and digitization of educational activities, with the educational industry being tasked with playing a role in offering new educational platforms. However, it is becoming increasingly clear that some types of learning cannot be replaced with online classes, and that it is difficult to provide field training remotely in medical education, long-term care, and the welfare sector [73].

The knowledge and findings obtained from this study make it possible to implement appropriate and specific support measures for educators, which the government and educational institutions are requested to tackle, and thereby improve the quality of education. Concerning educators' fear of COVID-19, our findings suggest that the higher their social capital, the greater their perception of increased burden at the sites of education. This is possibly because people with high social capital who carry out social activities other than at their place of work, such as volunteers, could no longer maintain social connections as before, or they may avoid making interpersonal contacts or exchanges during the COVID-19 pandemic; therefore, they had a greater perception of increased burden and anxiety. Offering professional assistance to teachers on learning management systems or digital technologies and assessing the influence of such technologies on educators are essential to sustain the delivery of education and guarantee its quality in the context of the COVID-19 pandemic. It is, thus, necessary to consider what kind of support should actually be provided and to whom, and to provide tailored assistance to prevent mental health problems and offer educational support. Shedding light on the educators' views on their burdens and anxiety related to implementing education will make it possible for the government and educational institutions to offer educators realistic and concrete support [74-78].

\section{Limitations}

This study has several limitations. First, because we used an Internet-based survey, it is possible that a large number of participants belonged to the Internet-using population, and that the perception of increased burden when teaching remote classes may be underestimated. Second, although we distributed the questionnaire with the intent of eliminating gender differences, the distribution of participants may indicate a gender bias. Third, we did not enquire about individual circumstances using free description. Further studies, using qualitative methods such as interview surveys, on educators' long-term 
conditions during and after the COVID-19 pandemic are needed. Fourth, the research period of our study was limited; therefore, future studies should consider the long-term impact of COVID-19 on educators. Fifth, our study period coincided with the development of COVID-19 vaccines globally; however, at the time of the study, the access to vaccines in Japan was limited. Therefore, further research is required to observe the changes amidst the vaccination rates and COVID-19 mutational conditions.

\section{Conclusions}

Our study identified the factors that induce stress and anxiety, such as economic and environmental factors, sociability, and isolation, as well as factors that cause individual differences. To secure opportunities for education in the context of the COVID-19 pandemic and to guarantee educational quality, it is essential to evaluate the pandemic's influence on educators. Educational institutions can provide better support to educators, made possible by shedding light on the mental health of not only students but also teachers as well as their perception of increased labor burden and factors that cause anxiety. Our study revealed that although the pandemic has not caused anxieties and fears that are serious enough to cause insomnia, it has increased the frequency at which the teachers use remote education techniques, cope with using the Internet, and deal with the students and their parents/guardians. Their labor time and financial burden have increased along with the fear of COVID-19. Moreover, educators who have an underlying disease, who are of advancing age, and who live with a family member at high infection risk bear a substantially heavy burden-material, economic, and mental - due to the need to implement infection countermeasures at the sites of education. It was also revealed that they are compelled to engage in educational activities while harboring anxieties in other educational areas, such as nurturing students' sociability as well as concerns about isolation of the self, colleagues, and family. Furthermore, since a strong correlation was found for factors such as SOC and age as predictive factors of teachers' perception of increased burden, it is important for educational institutions to provide educators with multidimensional support that is tailored to their individual characteristics.

Author Contributions: Conceptualization, Y.F. and K.F.; methodology, Y.F.; validation, Y.F. and K.F. formal analysis, Y.F.; investigation, Y.F.; resources, Y.F.; data curation, Y.F. and K.F.; writing-original draft preparation, Y.F.; writing-review and editing, Y.F. and K.F.; visualization, Y.F.; supervision, K.F.; project administration, Y.F.; funding acquisition, Y.F. and K.F. All authors have read and agreed to the published version of the manuscript.

Funding: This research was funded by Japan Society for the Promotion of Science KAKENHI, grant numbers 21K01308 and 20K10359.

Institutional Review Board Statement: The study was conducted according to the guidelines of the Declaration of Helsinki, and approved by the Research Ethics Review Board of Waseda University (No 2020-297; 30 November 2020).

Informed Consent Statement: Web-based written informed consent was obtained from all subjects involved in the study.

Data Availability Statement: The datasets generated and/or analyzed during the current study are available from the corresponding author on reasonable request.

Conflicts of Interest: The authors declare no conflict of interest. The funder had no role in the design of the study; in the collection, analyses, or interpretation of data; in the writing of the manuscript, or in the decision to publish the results. 


\section{References}

1. Ismail, S.A.; Saliba, V.; Lopez Bernal, J.; Ramsay, M.E.; Ladhani, S.N. SARS-CoV-2 infection and transmission in educational settings: A prospective, cross-sectional analysis of infection clusters and outbreaks in England. Lancet Infect. Dis. 2021, 21, 344-353. [CrossRef]

2. Irfan, O.; Li, J.; Tang, K.; Wang, Z.; Bhutta, Z.A. Risk of infection and transmission of SARS-CoV-2 among children and adolescents in households, communities and educational settings: A systematic review and meta-analysis. J. Glob. Health 2021, 11, 05013. [CrossRef] [PubMed]

3. Mossong, J.; Mombaerts, L.; Veiber, L.; Pastore, J.; Coroller, G.L.; Schnell, M.; Masi, S.; Huiart, L.; Wilmes, P. SARS-CoV-2 transmission in educational settings during an early summer epidemic wave in Luxembourg, 2020. BMC Infect. Dis. 2021, 21, 417. [CrossRef]

4. Buja, A.; Zabeo, F.; Cristofori, V.; Paganini, M.; Baldovin, T.; Fusinato, R.; Boccuzzo, G.; Cocchio, S.; Coretti, S.; Rebba, V.; et al Opening schools and trends in SARS-CoV-2 transmission in European countries. Int. J. Public Health 2021, 66, 1604076. [CrossRef] [PubMed]

5. Macartney, K.; Quinn, H.E.; Pillsbury, A.J.; Koirala, A.; Deng, L.; Winkler, N.; Katelaris, A.L.; O'Sullivan, M.V.N.; Dalton, C.; Wood, N.; et al. Transmission of SARS-CoV-2 in Australian educational settings: A prospective cohort study. Lancet Child Adolesc. Health 2020, 4, 807-816. [CrossRef]

6. Tupper, P.; Colijn, C. COVID-19 in schools: Mitigating classroom clusters in the context of variable transmission. PLoS Comput. Biol. 2021, 17, e1009120. [CrossRef] [PubMed]

7. Viner, R.M.; Russell, S.J.; Croker, H.; Packer, J.; Ward, J.; Stansfield, C.; Mytton, O.; Bonell, C.; Booy, R. School closure and management practices during coronavirus outbreaks including COVID-19: A rapid systematic review. Lancet Child Adolesc. Health 2020, 4, 397-404. [CrossRef]

8. Economic Commission for Latin America and the Caribbean; United Nations Educational, Scientific and Cultural Organization. Education in the Time of COVID-19. Available online: https:/ /www.cepal.org/sites/default/files/publication/files/45905/S200 0509_en.pdf (accessed on 14 August 2021).

9. Hanushek, E.A.; Woessmann, L. The Economic Impacts of Learning Losses. 2020. Available online: https://www.oecd.org/ education/The-economic-impacts-of-coronavirus-covid-19-learning-losses.pdf (accessed on 15 September 2021).

10. Pokhrel, S.; Chhetri, R. A literature review on impact of COVID-19 pandemic on teaching and learning. High. Educ. Future 2021, 8 133-141. [CrossRef]

11. World Health Organization. Schooling during COVID-19: Recommendations from the European Technical Advisory Group for Schooling during COVID-19. Available online: https:/ / apps.who.int/iris/bitstream/handle/10665/342075/WHO-EURO-2021 -2151-41906-59077-eng.pdf (accessed on 15 September 2021).

12. Grewenig, E.; Lergetporer, P.; Werner, K.; Woessmann, L.; Zierow, L. COVID-19 and educational inequality: How school closures affect low- and high-achieving students. Eur. Econ. Rev. 2021, 140, 103920. Available online: https://ftp.iza.org/dp13820.pdf (accessed on 15 September 2021). [CrossRef]

13. Chaturvedi, K.; Vishwakarma, D.K.; Singh, N. COVID-19 and its impact on education, social life and mental health of students: A survey. Child. Youth Serv. Rev. 2021, 121, 105866. [CrossRef]

14. Jojoa, M.; Lazaro, E.; Garcia-Zapirain, B.; Gonzalez, M.J.; Urizar, E. The impact of COVID 19 on university staff and students from Iberoamerica: Online learning and teaching experience. Int. J. Environ. Res. Public Health 2021, 18, 5820. [CrossRef] [PubMed]

15. Son, C.; Hegde, S.; Smith, A.; Wang, X.; Sasangohar, F. Effects of COVID-19 on college students' mental health in the United States: Interview survey study. J. Med. Internet Res. 2020, 22, e21279. [CrossRef] [PubMed]

16. Blake, H.; Knight, H.; Jia, R.; Corner, J.; Morling, J.R.; Denning, C.; Ball, J.K.; Bolton, K.; Figueredo, G.; Morris, D.E.; et al. Students' views towards SARS-CoV-2 mass asymptomatic testing, social distancing and self-isolation in a university setting during the COVID-19 pandemic: A qualitative study. Int. J. Environ. Res. Public Health 2021, 18, 4182. [CrossRef] [PubMed]

17. Organization for Economic Cooperation and Development. A Framework to Guide an Education Response to the COVID-19 Pandemic of 2020. Available online: https:/ / www.oecd-ilibrary.org/education/a-framework-to-guide-an-education-responseto-the-covid-19-pandemic-of-2020_6ae21003-en (accessed on 17 December 2021).

18. Pavlovic, A.; DeFina, L.F.; Natale, B.L.; Thiele, S.E.; Walker, T.J.; Craig, D.W.; Vint, G.R.; Leonard, D.; Haskell, W.L.; Kohl, H.W. Keeping children healthy during and after COVID-19 pandemic: Meeting youth physical activity needs. BMC Public Health 2021, 21, 485. [CrossRef]

19. Carrillo, C.; Flores, M.A. COVID-19 and teacher education: A literature review of online teaching and learning practices. Eur. J. Teach. Educ. 2020, 43, 466-487. [CrossRef]

20. Reimers, F.M.; Schleicher, A. Schooling Disrupted, Schooling Rethought: How the COVID-19 Pandemic is Changing Education. Available online: https: / / read.oecd-ilibrary.org/view / ?ref=133_133390-1rtuknc0hi\&title=Schooling-disrupted-schoolingrethought-How-the-Covid-19-pandemic-is-changing-education (accessed on 15 September 2021).

21. Kopilaš, V.; Hasratian, A.M.; Martinelli, L.; Ivkić, G.; Brajković, L.; Gajović, S. Self-perceived mental health status, digital activity, and physical distancing in the context of lockdown versus not-in-lockdown measures in Italy and Croatia: Cross-sectional study in the early ascending phase of the COVID-19 pandemic in March 2020. Front. Psychol. 2021, 12, 621633. [CrossRef] 
22. Baticulon, R.E.; Sy, J.J.; Alberto, N.R.I.; Baron, M.B.C.; Mabulay, R.E.C.; Rizada, L.G.T.; Tiu, C.J.S.; Clarion, C.A.; Reyes, J.C.B. Barriers to online learning in the time of COVID-19: A national survey of medical students in the Philippines. Med. Sci. Educ. 2021, 31, 615-626. [CrossRef]

23. Organization for Economic Cooperation and Development. Education at a Glance 2021: OECD Indicators; OECD Publishing: Paris, France, 2021. [CrossRef]

24. Cervantes-Guevara, G.; Maciel-Saldierna, M.; Elizondo-Hernández, E.; Cervantes-Pérez, L.A.; Cervantes-Cardona, G.A.; GarcíaReyna, B.; Ibarrola-Peña, J.C.; Almanza-Mena, Y.L.; Barbosa-Camacho, F.J.; Fuentes-Orozco, C.; et al. Fear of COVID-19 in high school personnel: A survey study in Western Mexico. Int. J. Ment. Health Addict. 2021, 1-8. [CrossRef]

25. Alnazly, E.; Khraisat, O.M.; Al-Bashaireh, A.M.; Bryant, C.L. Anxiety, depression, stress, fear and social support during COVID-19 pandemic among Jordanian healthcare workers. PLOS ONE 2021, 16, e0247679. [CrossRef]

26. Greenberg, N.; Docherty, M.; Gnanapragasam, S.; Wessely, S. Managing mental health challenges faced by healthcare workers during COVID-19 pandemic. BMJ 2020, 368, m1211. [CrossRef]

27. Shaukat, N.; Ali, D.M.; Razzak, J. Physical and mental health impacts of COVID-19 on healthcare workers: A scoping review. Int. J. Emerg. Med. 2020, 13, 40. [CrossRef] [PubMed]

28. Aperribai, L.; Cortabarria, L.; Aguirre, T.; Verche, E.; Borges, Á. Teacher's physical activity and mental health during lockdown due to the COVID-2019 pandemic. Front. Psychol. 2020, 11, 577886. [CrossRef] [PubMed]

29. Nabe-Nielsen, K.; Fuglsang, N.V.; Larsen, I.; Nilsson, C.J. COVID-19 risk management and emotional reactions to COVID-19 among school teachers in Denmark: Results from the CLASS study. J. Occup. Environ. Med. 2021, 63, 357-362. [CrossRef] [PubMed]

30. Ozamiz-Etxebarria, N.; Berasategi Santxo, N.; Idoiaga Mondragon, N.; Dosil Santamaría, M. The psychological state of teachers during the COVID-19 crisis: The challenge of returning to face-to-face teaching. Front. Psychol. 2020, 11, 620718. [CrossRef]

31. Sahu, P. Closure of universities due to coronavirus disease 2019 (COVID-19): Impact on education and mental health of students and academic staff. Cureus 2020, 12, e7541. [CrossRef]

32. Carlén, K.; Suominen, S.; Lindmark, U.; Saarinen, M.M.; Aromaa, M.; Rautava, P.; Sillanpää, M. Sense of coherence predicts adolescent mental health. J. Affect. Disord. 2020, 274, 1206-1210. [CrossRef]

33. Eriksson, M.; Lindström, B.; Lilja, J.A. A sense of coherence and health. Salutogenesis in a societal context: Aland, a special case? J. Epidemiol. Community Health 2007, 61, 684-688. [CrossRef]

34. Social Determinants of Health. Available online: https://www.healthypeople.gov/2020/topics-objectives/topic/socialdeterminants-of-health (accessed on 6 January 2022).

35. Hanifan, L.J. The rural school community center. ANNALS Am. Acad. Political Soc. Sci. 1916, 67, 130-138. [CrossRef]

36. Bourdieu, P. The Forms of Capital. In Handbook of Theory and Research for the Sociology of Education; Richardson, J., Ed.; Greenwood: New York, NY, USA, 1986; pp. 241-258.

37. Coleman, Z.W. Social Theory for a Changing Society; Bourdieu, P., Coleman, J.S., Eds.; Westview Press: Boulder, CO, USA, 1991.

38. Putnam, R.D. Bowling Alone: The Collapse and Revival of American Community; Simon \& Schuster: New York, NY, USA, 2000.

39. Berkman, L.F.; Kawachi, I. (Eds.) Social Epidemiology; Oxford University Press: Oxford, UK, 2000.

40. Tarlov, A.R. Public policy frameworks for improving population health. Ann. N. Y. Acad. Sci. 1999, 896, 281-293. [CrossRef]

41. Bartscher, A.K.; Seitz, S.; Siegloch, S.; Slotwinski, M.; Wehrhöfer, N. Social capital and the spread of COVID-19: Insights from European countries. J. Health Econ. 2021, 80, 102531. [CrossRef]

42. Pressley, T. Factors contributing to teacher burnout during COVID-19. Educ. Res. 2021, 50, 325-327. [CrossRef]

43. Sánchez-Pujalte, L.; Mateu, D.N.; Etchezahar, E.; Gómez Yepes, T. Teachers' burnout during COVID-19 pandemic in Spain: Trait emotional intelligence and socioemotional competencies. Sustainability 2021, 13, 7259. [CrossRef]

44. Murphy, L.R. Job Stress Research at NIOSH: 1972-2002. In Research in Occupational Stress and Well Being; Historical and Current Perspectives on Stress and Health; Perrewe, P.L., Ganster, D.C., Eds.; Emerald Group Publishing Limited: Bingley, UK, 2002; Volume 2, pp. 1-55.

45. Kachi, Y.; Inoue, A.; Eguchi, H.; Kawakami, N.; Shimazu, A.; Tsutsumi, A. Occupational stress and the risk of turnover: A large prospective cohort study of employees in Japan. BMC Public Health 2020, 20, 174. [CrossRef] [PubMed]

46. Jones, A.L.; Kessler, M.A. Teachers' emotion and identity work during a pandemic. Front. Educ. 2020, 5, 583775. [CrossRef]

47. Togari, T.; Yamazaki, Y.; Nakayama, K.; Yokoyama, Y.; Yonekura, Y.; Takeuchi, T. Nationally representative score of the Japanese language version of the 13-item 7-point sense of coherence scale. Nihon Koshu Eisei Zasshi 2015, 62, $232-237$.

48. Saito, M.; Kondo, N.; Aida, J.; Kawachi, I.; Koyama, S.; Ojima, T.; Kondo, K. Development of an instrument for community-level health related social capital among Japanese older people: The JAGES Project. J. Epidemiol. 2017, 27, 221-227. [CrossRef]

49. Elemo, A.S.; Satici, S.A.; Griffiths, M.D. The Fear of COVID-19 scale: Psychometric properties of the Ethiopian Amharic version. Int. J. Ment. Health Addict. 2020, 1-12. [CrossRef]

50. Martínez-Lorca, M.; Martínez-Lorca, A.; Criado-Álvarez, J.J.; Armesilla, M.D.C.; Latorre, J.M. The Fear of COVID-19 scale: Validation in Spanish university students. Psychiatry Res. 2020, 293, 113350. [CrossRef]

51. Tzur Bitan, D.T.; Grossman-Giron, A.; Bloch, Y.; Mayer, Y.; Shiffman, N.; Mendlovic, S. Fear of COVID-19 scale: Psychometric characteristics, reliability and validity in the Israeli population. Psychiatry Res. 2020, 289, 113100. [CrossRef]

52. Wakashima, K.; Asai, K.; Kobayashi, D.; Koiwa, K.; Kamoshida, S.; Sakuraba, M. The Japanese version of the Fear of Covid-19 scale: Reliability, validity, and relation to coping behavior. PLoS ONE 2020, 15, e0241958. [CrossRef] 
53. Marelli, S.; Castelnuovo, A.; Somma, A.; Castronovo, V.; Mombelli, S.; Bottoni, D.; Leitner, C.; Fossati, A.; Ferini-Strambi, L. Impact of COVID-19 lockdown on sleep quality in university students and administration staff. J. Neurol. 2021, 268, 8-15. [CrossRef] [PubMed]

54. He, J.; He, L.; Zhou, W.; Nie, X.; He, M. Discrimination and social exclusion in the outbreak of COVID-19. Int. J. Environ. Res. Public Health 2020, 17, 2933. [CrossRef] [PubMed]

55. Kim, L.E.; Leary, R.; Asbury, K. Teachers' Narratives during COVID-19 partial school reopenings: An exploratory study. Educ. Res. 2021, 63, 244-260. [CrossRef]

56. Yağar, F. Fear of COVID-19 and its association with health literacy in elderly patients. J. Patient Exp. 2021, 8, 23743735211056506. [CrossRef]

57. Mistry, S.K.; Ali, A.R.M.M.; Akther, F.; Yadav, U.N.; Harris, M.F. Exploring fear of COVID-19 and its correlates among older adults in Bangladesh. Glob. Health 2021, 17, 47. [CrossRef]

58. Nicola, M.; Alsafi, Z.; Sohrabi, C.; Kerwan, A.; Al-Jabir, A.; Iosifidis, C.; Agha, M.; Agha, R. The socio-economic implications of the coronavirus pandemic (COVID-19): A review. Int. J. Surg. 2020, 78, 185-193. [CrossRef]

59. Akour, A.; Al-Tammemi, A.B.; Barakat, M.; Kanj, R.; Fakhouri, H.N.; Malkawi, A.; Musleh, G. The impact of the COVID-19 pandemic and emergency distance teaching on the psychological status of university teachers: A cross-sectional study in Jordan Am. J. Trop. Med. Hyg. 2020, 103, 2391-2399. [CrossRef]

60. Hidalgo-Andrade, P.; Hermosa-Bosano, C.; Paz, C. Teachers' mental health and self-reported coping strategies during the COVID-19 pandemic in Ecuador: A mixed-methods study. Psychol. Res. Behav. Manag. 2021, 14, 933-944. [CrossRef]

61. Penado Abilleira, M.P.; Rodicio-García, M.L.; Ríos-de Deus, M.P.; Mosquera-González, M.J. Technostress in Spanish university teachers during the COVID-19 pandemic. Front. Psychol. 2021, 12, 617650. [CrossRef]

62. Worth, J.; Van den Brande, J. Teacher Labour Market in England. Annual Report 2019. Available online: https://www.nfer.ac.uk/ media/3344/teacher_labour_market_in_england_2019.pdf (accessed on 15 September 2021).

63. Perryman, J.; Calvert, G. What motivates people to teach, and why do they leave? accountability, performativity and teacher retention. Br. J. Educ. Stud. 2020, 68, 3-23. [CrossRef]

64. Oducado, R.M.; Rabacal, J.; Moralista, R.; Tamdang, K. Perceived stress due to COVID-19 pandemic among employed professional teachers. J. Educ. Res. Innov. 2021, 15, 305-316. [CrossRef]

65. Al-Sabba, S.; Darwish, A.; Fares, N.; Barnes, J.; Almomani, J.A. Biopsychosocial factors linked with overall well-being of students and educators during the COVID-19 pandemic. Cogent Psychol. 2021, 8, 1875550. [CrossRef]

66. Eadie, P.; Levickis, P.; Murray, L.; Page, J.; Elek, C.; Church, A. Early childhood educators' wellbeing during the COVID-19 pandemic. Early Child Educ. J. 2021, 49, 903-913. [CrossRef] [PubMed]

67. Spadafora, N.; Reid-Westoby, C.; Pottruff, M.; Janus, M. Family responsibilities and mental health of kindergarten educators during the first COVID-19 pandemic lockdown in Ontario, Canada. medRxiv 2021. [CrossRef]

68. Kuwato, M.; Hirano, Y. Sense of coherence, occupational stressors, and mental health among Japanese high school teachers in Nagasaki Prefecture: A multiple regression analysis. BMC Public Health 2020, 20, 1355. [CrossRef]

69. Mc Gee, S.L.; Höltge, J.; Maercker, A.; Thoma, M.V. Sense of coherence and stress-related resilience: Investigating the mediating and moderating mechanisms in the development of resilience following stress or adversity. Front. Psychiatry 2018, 9, 378. [CrossRef]

70. Lizana, P.A.; Vega-Fernadez, G.; Gomez-Bruton, A.; Leyton, B.; Lera, L. Impact of the COVID-19 pandemic on teacher quality of life: A longitudinal study from before and during the health crisis. Int. J. Environ. Res. Public Health 2021, 18, 3764. [CrossRef]

71. Landicho, J.B. Social capital perspective of English teachers' professional identity in an online community. Int. J. Educ. Sci. 2021, 32, 137-148. [CrossRef]

72. Bai, J.; Jin, W.; Wan, C. The impact of social capital on individual responses to COVID-19 pandemic: Evidence from social distancing. SSRN J. 2020. [CrossRef]

73. O'Doherty, D.; Dromey, M.; Lougheed, J.; Hannigan, A.; Last, J.; McGrath, D. Barriers and solutions to online learning in medical education-An integrative review. BMC Med. Educ. 2018, 18, 130. [CrossRef]

74. Cohen, A.K.; Hoyt, L.T.; Dull, B. A descriptive study of COVID-19-related experiences and perspectives of a national sample of college students in spring 2020. J. Adolesc. Health 2020, 67, 369-375. [CrossRef] [PubMed]

75. Daniel, S.J. Education and the COVID-19 pandemic. Prospects 2020, 49, 91-96. [CrossRef] [PubMed]

76. Fantini, M.P.; Reno, C.; Biserni, G.B.; Savoia, E.; Lanari, M. COVID-19 and the re-opening of schools: A policy maker's dilemma. Ital. J. Pediatr. 2020, 46, 79. [CrossRef] [PubMed]

77. Mohmmed, A.O.; Khidhir, B.A.; Nazeer, A.; Vijayan, V.J. Emergency remote teaching during coronavirus pandemic: The current trend and future directive at Middle East College Oman. Innov. Infrastruct. Solut. 2020, 5, 72. [CrossRef]

78. Odriozola-González, P.; Planchuelo-Gómez, Á.; Irurtia, M.J.; de Luis-García, R. Psychological effects of the COVID-19 outbreak and lockdown among students and workers of a Spanish university. Psychiatry Res. 2020, 290, 113108. [CrossRef] 